Submitted on June 3, 2020.

\title{
Comparative kinetic studies of the chemical deposition of PbSe with sodium selenosulfate and selenourea with the establishment of the influence of their nature on the composition and morphology of the films
}

\author{
(C) Anastasia V. Beltseva, ${ }^{1}$ Vyatcheslav F. Markov, ${ }^{1,2 *}$ and Larisa N. Maskaeva ${ }^{1,2+}$ \\ ${ }^{1}$ Physical and Colloid Chemistry department. Ural Federal University named after the first President \\ of Russia B.N. Yeltsin. Mira St., 19. Yekaterinburg, 620002. Sverdlovsk Region. Russia. \\ Phone:+7(343)375-93-18.E-mail:mln@ural.ru \\ ${ }^{2}$ Chemistry and Combustion Process department. Ural State Fire Service Institute of Emergency ministry \\ of Russia. St. Mira, 22. Yekaterinburg, 620022. Sverdlovsk Region. Russia. Phone: +7 (343) 360-81-68.
}

\begin{abstract}
*Supervising author; ${ }^{+}$Corresponding author
Keywords: kinetic study, sodium selenosulfate, selenocarbamide, activation energy of chemical reaction, hydrochemical deposition, films, lead selenide.
\end{abstract}

\begin{abstract}
After analyzing the literature, one can note the increased interest in lead selenide in the thin-film state, used in various fields: from microelectronics to solar energy converters. There are physical and chemical methods for producing PbSe films, each of which has its own advantages and disadvantages. However, researchers prefer chemical deposition from aqueous media, which eliminates the need for complex, expensive equipment, heating to high temperatures and creating high pressures. The Ural school of thin-film synthesis has developed and tested a kinetic-thermodynamic method for predicting the chemical deposition of metal chalcogenides. The thermodynamic assessment carried out in our previous publication indicated only the principal possibility of the formation of lead selenide when using selenocarbamide $\mathrm{CSe}\left(\mathrm{NH}_{2}\right)_{2}$ and sodium selenosulfate $\mathrm{Na}_{2} \mathrm{SeSO}_{3}$. For a more complete understanding of this process, a comprehensive approach is necessary, taking into account the patterns of the deposition of the solid phase of $\mathrm{PbSe}$ in time, depending on thermodynamic factors - temperature and concentration of reagents. Therefore, in this work, we studied the kinetics of the chemical deposition of lead selenide with selenourea and sodium selenosulfate from solutions containing lead acetate, sodium citrate, ammonium hydroxide and iodide, in the temperature $303-353 \mathrm{~K}$ under conditions of spontaneous nucleation of the solid phase. As a result of the studies, the partial kinetic reaction orders for chalcogenizers were determined, amounting to $0.86\left(\mathrm{CSe}\left(\mathrm{NH}_{2}\right)_{2}\right)$ and $0.78\left(\mathrm{Na}_{2} \mathrm{SeSO}_{3}\right)$, as well as the activation energy of the formation of lead selenide, which amounted to 45.1 and $25.07 \mathrm{~kJ} / \mathrm{mole}$, respectively. Hydrochemical deposition of selenocarbamide and sodium selenosulfate produced $\mathrm{PbSe}$ films on substrates of sitall and glass with a thickness of 200-300 nm. Energy dispersive analysis and scanning electron microscopy showed the influence of the nature of the substrate, type chalcogenizer on the morphology, particle size distribution and elemental composition of lead selenide layers. An elemental analysis showed that $\mathrm{PbSe}$ films precipitated with sodium selenosulfate contain an excess of lead compared to selenium $(\mathrm{Pb} / \mathrm{Se}=1.25-$ $1.32)$, and the stoichiometric composition ensures the use of selenocarbamide $(\mathrm{Pb} / \mathrm{Se}=0.99-1.05)$.
\end{abstract}

\section{References}

[1] A.I. Dirochka, M.D. Korneeva, A.M. Filachev. Photoelectronics of the XXI century. Applied Physics. 2011. Vol.2. P.37-46. (russian)

[2] N.A. Kulchitsky, A.V. Naumov. Modern optoelectronic devices based on zinc selenide. Nanoengineering. 2014. Vol.11. No.41. P.19-27. (russian)

[3] M.P. Mironov, V.F. Dyakov, V.F. Markov, L.N. Maskaeva. Highly sensitive high-speed IR detectors for monitoring overheating of axleboxes of railway vehicle rolling stock. Fire and explosion safety. 2009. Vol.18. P.29-31. (russian)

[4] J.B. Seung, K. Kim, K.S. Lim, S.M. Jung, Y.-C. Park, D.G. Han, S. Lim, S. Yoo, S. Jeong. Lowtemperature annealing for highly conductive lead chalcogenide quantum dot solids. J. Phys. Chem. C. 2011. Vol.115. P.607-612. 
COMPARATIVE KINETIC STUDIES OF THE CHEMICAL DEPOSITION OF PbSe WITH SODIUM...

[5] L. Hu, S. Huang, R. Patterson, J.E. Halpert. Enhanced mobility in PbS quantum dot films via PbSe quantum dot mixing for optoelectronic applications. J. Mater. Chem. C. 2019. Vol.7. P.4497-4502.

[6] Z. Chen, Z. Zhang, J. Yang, W. Chen, Z.L. Teh, D. Wang, L. Yuan, J. Zhang, J.A. Stride, G.J. Conibeer, R.J. Patterson, S. Huang. Improving carrier extraction in a PbSe quantum dot solar cell by introducing a solution-processed antimony-doped $\mathrm{SnO}_{2}$ buffer layer. J. Mater. Chem. C. 2018. Vol.6. P.9861-9866.

[7] J. Androulakis, I. Todorov, J. He, D.-Y. Chung, V. Dravid, M. Kanatzidis. Thermoelectrics From Abundant Chemical Elements: High-Performance Nanostructured PbSe-PbS. Am.Chem. Soc. 2011. Vol.133. P.10920-10927.

[8] S.A. Yamini, M. Brewis, J. Byrnes, R. Santos, A. Manettasa, Y.Z. Pei. Fabrication of thermoelectric materials -thermal stability and repeatability of achieved efficiencies. J.Mater. Chem. C. 2015. Vol.3. P.10610.

[9] S. Jin, Y. Hu, Z. Gu, L. Liu, H.-C. Wu. Application of quantum dots in biological imaging. J. Nanomater. 2011. P.834139.

[10] A.G. Makarov, D.A. Razdobreev, M.O. Sagida. The sensors based on iron chalcogenides. Bulletin of OSU. 2014. Vol 6. No.167. P.224-229. (russian)

[11] S. Wang, T. Shen, H. Bai, B. Li, J. Tian. $\mathrm{Cu}_{3} \mathrm{Se}_{2}$ nanostructure as a counter electrode for high efficiency quantum dot-sensitized solar cells. J. Mater. Chem. C. 2016. Vol.34. P.8020-8026.

[12] M.A. Barote, B.D. Ingale, R.V. Surywanshi, T.V. Chavan, E.U. Masumdar. Growth and Characterization of Chemical bath Deposited Polycrystalline n-PbSe thin films. Res. J. Chem. Sci. 2011. Vol.1. P.48-50.

[13] L.N. Maskaeva, V.M. Yurk, V.F. Markov, M.V. Kuznetsov, V.I. Voronin, R.D. Muhamediarov, G.V. Zyrianov. Composition, structure and functional properties of nanostructured PbSe films deposited using different antioxidants. Materials Science in Semiconductor Processing. 2020. Vol.108. P.104867.

[14] E. Díaz-Torres, M. Ortega-López, Y. Matsumoto, J. Santoyo-Salazar. Simple synthesis of PbSe nanocrystals and their self-assembly into 2D 'flakes' and 1D 'ribbons' structures. Mater. Research Bulletin. 2016. Vol.80. P.96-101.

[15] Y.X. Ren, T.J. Dai, W.B. Luo, X.Z. Liu. Evidences of sensitization mechanism for PbSe thin films photoconductor. Vacuum. 2018. Vol.149. P.190.

[16] J. Qiu, B. Weng, Z. Yuan, Z. Shi. Study of Sensitization Process on Mid-Infrared Uncooled PbSe Photoconductive Detectors Leads to High Detectivity. J. of Appl. Phys. 2013. Vol.113. P.103102.

[17] S. Kukunuri, M.R. Krishnan, S. Sampath. The effect of structural dimensionality on the electrocatalytic properties of the nickel selenide phase. Phys.Chem. 2015. Vol.17. P.23448-23459.

[18] G.L. Agawane, S.W. Shin, M.P. Suryawanshi, K.V. Gurav, A.V. Moholkar, J.Y. Lee, P.S. Patil, J.H. Yun, J.H. Kim. Preparation and characterization of chemical bath deposited nanocrystalline ZnSe thin films using Na3-citrate and hydrazine. Mater. Letters. 2013. Vol.106. P.186-189.

[19] G. Almeida, S. Dogan, G. Bertoni, C. Giannini, R. Gaspari, S. Perissinotto, R. Krahne, S. Ghosh, L. Manna. Colloidal Monolayer $\beta-\mathrm{In}_{2} \mathrm{Se}_{3}$ Nanosheets with High Photoresponsivity. J. Am. Chem. Soc. 2017. Vol.139. P.3005-3011.

[20] I.V. Yanitsky, V.I. Zelionkaite, E.I. Patsaskas. Analysis of mixtures of some oxygen compounds of selenium and sulfur. J. Inor. Chem. 1957. Vol.2. No.6. P.1341-1348. (russian)

[21] D.G. Knorre, L.F. Krylova, V.S. Musicians. Physical chemistry. Vol.1: 2nd ed., Rev. and add. Moscow: Higher school. 1990. 416p. (russian)

[22] G. Shvarzenbah, G. Flashka. Complexonometricheskoe titrovanie [Complexometric titration]. Moscow: Chemistry. 1970. 360p. (russian)

[23] L.N. Maskaeva, G.A. Kitaev, L.G. Zhidkova, L.E. Vasyunina. Investigation of Cr (VI) reduction by polyolefins. J. Phys.Chem. 1975. Vol.69. No.4. P.1042-1044. (russian)

[24] V.F. Markov, M.P. Mironov, L.N. Maskaeva, and S.V. Brezhnev. Kinetic-thermodynamic determination of forming conditions For lead selenide in ethylene diamine - acetate system. Butlerov Communications. 2009. Vol.17. No.6. P.22-32. ROI-jbc-02/09-17-6-22

[25] V.F. Markov, N.V. Zamaraeva, I.V. Zarubin, V.M. Bakanov, and L.N. Maskaeva. Hydrochemical synthesis of metal chalcogenide films. Part 9. Kinetics of chemical bath deposition of lead selenide from a citrate-ammonia system. Butlerov Communications. 2011. Vol.26. No.12. P.37-44. ROI-jbc-02/11-26$12-37$

[26] N.A. Tretyakova, V.F. Markov, L.N. Maskaeva, H.N. Mukhamedzyanov. Kinetics of hydrochemical deposition of lead selenide films, their composition, structure and properties. Condensed matter and interface. 2005. Vol.7. No.2. P.189-194. (russian)

[27] A.G. Stromberg, D.P. Semchenko. Physical chemistry. Vol.1. Moscow: Higher school. 2001. 572p. (russian) 
[28] V.V. Afrosimov, R.N. Il'in, S.F. Karmanenko, V.I. Sakharov, I.T. Serenkov. Effect of substrates on the morphology of $\mathrm{Ba}_{\mathrm{x}} \mathrm{Sr}_{1-\mathrm{x}} \mathrm{TiO}_{3}$ nanometer-scale films. Physics of the Solid State. 2003. Vol.45. No.6. P.1122-1127. (russian)

[29] I.V. Antonets, E.A. Golubev, L.N. Kotov. The effect of substrates on the formation of the surface relief of thin metal films. J. of Surface Investigation: X-ray, Synchrotron and Neutron Techniques. 2007. No.7. P.65-71. (russian)

[30] V.P. Veiko, K.K. Kieu. Laser amorphisation of glass ceramics: basic properties and new possibilities for manufacturing microoptical elements. Quantum Electronics. 2007. Vol.37. No.1. P.92-98. (russian) 